the manufacture of semiconductor silicon material continued on a profitable basis despite considerable market price pressure. The production of nuclear fuel elements and cores, mainly for the Navy's propulsion programme, also continued. Texas Instrumonts is the main contractor for the electronic equipment of the naval Shrike air-tosurface missile, and the programme has now advanced from the development to the manufacturing stage. Prototype advanced radar and infra-red systems for the Air Force's new reconraaissance fighter aircraft $R F 4 C$ were delivered, with production scheduled for 1964. New sales records were established by the Company's petroleum exploration activities and in applications of Earth, ocean and space sciences. Contracts were obtained to develop a major multi-sensor shipboard survey system which will perform and record simultaneously many oceanographic tests such as those for temperature, gravity and magnetic measurements, and to find the best methods to make scientific measurements and geophysical investigations during the Apollo visit to the Moon. Expenditure on development or application of now or modified products, services, equipment or processes totalled about 45 million dollars, of which about 25 million dollars was from outside contracts, mainly with the Government of the United States. Business in Europe exceeded expectations, and was good both in Latin America and Australia. Texas Instruments France moved into a new $60,000 \mathrm{ft} .{ }^{2}$ semiconductor plant near Nice and an additional plant of $59,000 \mathrm{ft}^{2}$ for metal fabrication was leased in Australia. A new plant was opened at Toronto, Canada, for control device manufacture, and construction will shortly begin on a similar plant near Aversa, Italy. Approximately 18 per cent of the total net sales of the Company were from operations in countries outside the United States.

\section{Preparation and Properties of bis-Hydrazides and Related Compounds}

C. N. O'Callaghan and Dermot Twomey, of the Medical Research Council of Ireland, Trinity College, Dublin, have described the preparation and properties of bis-hydrazides and related compounds (Proceedings of the Royal Irish Academy, 63, Section B, No. 12: Antitubercular Substances; 19: The Preparation and Properties of bis-Hydrazides and Related Compounds. 1964. 1s.6d.). Since the discovery of the anti-tuberculosis properties of isoniazid, considerable attention has been directed to the preparation of compounds containing hydrazide group. ings. Apart from mono-hydrazides, anti-tuberculosis properties have also been ascribed to various bis-hydrazides and structurally related compounds. One of the latter, cyanoacetohydrazide, has been thoroughly examined; despite conflicting reports, it is now generally considered to be much less active in vivo than isoniazid. A feature of compounds such as ethyl malonate, ethyl cyanoacetate and ethyl acetoacetate, which contain a reactive methylene group, is the ease with which they undergo the well-known Knoevenegel reaction with aldehydes and ketones to yield a series of compounds of type $\mathrm{I}$, where $R$ is $\mathrm{CO}_{2} \mathrm{Et}, \mathrm{CN}$ and $\mathrm{COCH}_{3}$, respectively. The reaction of these condensation products with hydrazine has been investigated.

\section{British Geological Literature}

Among the recommendations of the British Commonwealth Official Conference on Geology and Mineral Resources, which met in London in 1948, there is one that "The Geological Survey (or other appropriate authorities) throughout the British Commonwealth should each take steps to publish an annual volume of abstracts of all geological papers published relating to the territories for which they are respectively responsible". In most Commonwealth countries this proposal has long since been implemented; but in Britain not even an annual bibliography of geological works, far less a volume of abstracts, has been available in post-war years. A special welcome must therefore be extended to a new unofficial publication, British Geological Literature, compiled by E. L. Martin, of the Geological Survey, and A. P. Harvey, of the British Museum (Natural History), the first part of which lists nearly 300 references published early in 1964. British Geological Literature (Coridon Press, 35 Goddington Road, Bourne End, Bucks. £l per annum) will be published quarterly, with annual author and subject indexes; and a loose-sheet edition for card-index catalogues is also being produced. The compilers are to be congratulated on their initiative, which deserves every support. Perhaps it is not too much to hope that their modest publication may expand into the much-needed journal of abstracts which the appropriate authorities have as yet been unable to produce.

\section{Last Cretaceous Vertebrates}

Two papers recently issued as University of California Publications in Geological Sciences add much to our knowledge of the vertebrate faunas near the critical Mesozoic-Conozoic boundary. In a re-investigation of the Lance Formation in Wyoming, Dr. R. Histes reports on the palæoecology and zoogeography with details of the non-mammalian vertebrate fauna and a brief account of the flora and invertebrate fauna (49: Fossil Vertebrates from the Late Cretaceous Lance Formation, Eastern Wyoming. Pp. $180+5$ plates. Berkeley and Los Angeles: University of California Press; London: Cambridge University Press, 1964. 4 dollars). Dr. W. A. Clemens deals with the Multituberculata in the first part of a publication and will deal with the metatherians and eutherians in later parts (48: Fossil Mammals of the Type Lance Formation, Wyoming. Part 1: Introduction and Multituberculata. Pp. 1-105. Berkeley and Los Angeles: University of Cailfornia Press; London: Cambridge University Press, 1963. 2.50 dollars). The authors have been fortunate in obtaining extensive new collections by underwater screening of the matrix, so concentrating a microfauna of more than 30,000 specimens. Five multituberculate genera, including a new species, are described and all referred to the Ptilodontidae. The reptile fauna comprises an eosuchian, six turtles, fourteen lizards, a snake, two crocodiles and eight dinosaurs, the latter with theropods, carnosaurs and ornithischians. A good amphibian fauna is represented by both salientes and urodeles. The fish include sharks, sturgeon, amiids and gar. Estes is able to confirm the fresh-water character of the formation investigated, with sub-tropical climate prevalent. 'The environment envisaged is a warm, humid, coastal plain with abundant riparian habitats and rich vertebrate fauna. The remaining parts of these investigations will be keenly awaited, the rare combination of Mesozoic and modern elements in the biota making it of especial interest.

\section{Locomotion in Antarctic Seals}

Fergus O'Gorman, of tho British Antarctic Survey and the Anatomy Department, Charing Cross Hospital Medical School (London), has made observations on the modes of terrestrial locomotion among Antaretic members of the Phocidae (Proc. Zool. Soc. London, 141, Part 4; 1963). An account is given of the sinuous or 'swimming' type of progression which is particularly developed in the crab-eater seal, Lobodon carcinophagus (Hombron and Jac. quinot), and is also seen in the leopard seal, Hydrurga leptonyx (Blainville). This type of movement has not been seen in the Weddell seal, Leptonychotes weddelli Lesson, where the undulatory (caterpillar-like) method is the normal locomotory pattern on land. The fore-flippers are not used by the adult Weddell seal in terrestrial locomotion, but the pup does make some use of the foreflippers during its first 10-15 days. 